Tiedemann, R., Mix, A.C., Richter, C., and Ruddiman, W.F. (Eds.)

Proceedings of the Ocean Drilling Program, Scientific Results Volume 202

\section{Magnetostratigraphic \\ Calibration of the Late Oligocene Climate Transition ${ }^{1}$}

\author{
Benjamin P. Flower ${ }^{2}$ and Kathryn E. Chisholm ${ }^{3}$
}

\begin{abstract}
Magnetic polarity stratigraphy and stable isotope data from Ocean Drilling Program Leg 202 Core 202-1237B-31H allow calibration of the late Oligocene climate transition to the geomagnetic polarity timescale (GTS 2004). Oxygen isotope $\left(\delta^{18} \mathrm{O}\right)$ values in the benthic foraminifer Cibicidoides mundulus decrease from $\sim 2.20 \%$ in upper Chron 9n (Oi2b) to $\sim 1.90 \%$ in upper Chron 8 r. The mean decrease is smaller than suggested by a recent compilation of benthic foraminifer $\delta^{18} \mathrm{O}$ records. The decrease occurs in three steps from 323 to 321 meters composite depth (mcd) within Chron 8r (27.027-26.554 Ma), and is here termed the "Chron 8r $\delta^{18} \mathrm{O}$ shift." Linear interpolation within Chron 8r estimates an age of $26.35 \mathrm{Ma}$ for the final decrease to lower values marking initiation of the late Oligocene climatic optimum. The initial decrease at 26.7 Ma is closely associated with the last occurrence of Paragloborotalia opima (P21/P22 planktonic foraminifer zonal boundary) between 322.51 and 322.76 mcd in lowermost Chron 8r. This study is a modest step toward an integrated magnetic polarity and astronomical chronostratigraphy for the late Oligocene based on Site 1237.
\end{abstract}

\section{INTRODUCTION}

Oxygen isotope data on benthic foraminifers from deep-sea cores have provided a useful history of Cenozoic climate change. Existing records exhibit minimum values during the early Eocene, consistent with an ice-free world with very warm deep-sea temperatures reaching
${ }^{1}$ Flower, B.P., and Chisholm, K.E., 2006. Magnetostratigraphic calibration of the late Oligocene climate transition. In Tiedemann, R., Mix, A.C., Richter, C., and Ruddiman, W.F. (Eds.), Proc. ODP, Sci. Results, 202: College Station, TX (Ocean Drilling Program), 1-15. doi:10.2973/ odp.proc.sr.202.204.2006

${ }^{2}$ College of Marine Science, University of South Florida, St. Petersburg FL

33701, USA. bflower@marine.usf.edu ${ }^{3}$ Collegium of Natural Sciences, Eckerd College, St. Petersburg FL 33711, USA.

Initial receipt: 27 September 2004 Acceptance: 2 November 2005

Web publication: 14 April 2006

Ms 202SR-204 
$\sim 12^{\circ} \mathrm{C}$ (Miller et al., 1987; Zachos et al., 2001) (Fig. F1). The early Eocene is inferred to be the warmest $>1-\mathrm{m}$.y. interval of the past $70 \mathrm{~m} . \mathrm{y}$. and is generally considered a "greenhouse world." Based on a recent global compilation of deep-sea benthic foraminifer oxygen isotope records (Zachos et al., 2001), the long-term increase in Cenozoic $\delta^{18} \mathrm{O}$ of $\sim 3.2 \%$ must reflect some combination of deep-sea cooling and polar ice sheet growth. Because present-day ice sheets account for $\sim 1 \%$ o equivalent $\delta^{18} \mathrm{O}$, the remaining 2.2\%o is consistent with cooling of $9^{\circ}-$ $11^{\circ} \mathrm{C}$ over the course of the Cenozoic (Miller et al., 1987; Flower, 1999; Zachos et al., 2001). Three rapid increases in benthic $\delta^{18} \mathrm{O}$ are generally inferred to include significant ice sheet growth, including increases near the Eocene/Oligocene boundary at $\sim 33.5 \mathrm{Ma}$, during the middle Miocene at $\sim 14 \mathrm{Ma}$, and during the late Pliocene at $\sim 2.75 \mathrm{Ma}$.

The long-term increase in benthic $\delta^{18} \mathrm{O}$ is interrupted by two major decreases during the late Oligocene at $\sim 26 \mathrm{Ma}$ and the early Miocene at $\sim 17 \mathrm{Ma}$ (Zachos et al., 2001). Compilation data from the late Oligocene suggest a $>1 \%$ decrease in $\delta^{18} \mathrm{O}$ following oxygen isotope event Oi2b (Miller et al., 1991) at $26 \mathrm{Ma}$ (Fig. F1). This decrease is attributed to a combination of deep-sea warming and Antarctic ice volume decrease (Miller et al., 1988, 1991; Zachos et al., 2001), leading to the peak of late Oligocene warmth. Significantly, data prior to the excursion come primarily from southern Indian Ocean Site 744 on Kerguelen Plateau $\left(61^{\circ} 34.66^{\prime} \mathrm{S}, 80^{\circ} 35.46^{\prime} \mathrm{E}\right.$; water depth $\left.=2307 \mathrm{~m}\right)$, whereas those afterward come from equatorial Atlantic Ocean Drilling Program (ODP) Site 929 on Ceara Rise $\left(5^{\circ} 58.57^{\prime} \mathrm{N}, 43^{\circ} 44.4^{\prime} \mathrm{W}\right.$; water depth $\left.=4356 \mathrm{~m}\right)$. Consequently, the magnitude and rapidity of the benthic $\delta^{18} \mathrm{O}$ decrease is uncertain because few continuous high-resolution records with paleomagnetic age control exist for the late Oligocene.

Deconvolving the ice volume and temperature components of the benthic $\delta^{18} \mathrm{O}$ signal is a continuing challenge in Cenozoic paleoceanography. $\mathrm{Mg} / \mathrm{Ca}$ data on benthic foraminifers provide an independent means to track Cenozoic deep-sea temperature history (Lear et al., 2000, 2004; Martin et al., 2002; Billups and Schrag, 2002). Furthermore, the combination of $\mathrm{Mg} / \mathrm{Ca}$ and $\delta^{18} \mathrm{O}$ analyses in benthic foraminifers allows separation of temperature effects and isolation of the $\delta^{18} \mathrm{O}$ composition of seawater $\left(\delta^{18} \mathrm{O}_{\mathrm{sw}}\right)$. Existing $\mathrm{Mg} / \mathrm{Ca}$ records exhibit a complex relationship to the benthic $\delta^{18} \mathrm{O}$ compilation (Lear et al., 2000, 2004). Indeed, substantial mismatches are apparent in the late Oligocene and early Miocene. Deep-sea temperatures exhibit no mean increase during the late Oligocene that might parallel the benthic $\delta^{18} \mathrm{O}$ decrease (Fig. F1), although they exhibit considerable variability of $\sim 2^{\circ} \mathrm{C}$ (Lear et al., 2004). Accordingly, the late Oligocene benthic $\delta^{18} \mathrm{O}$ decrease must mainly reflect $\delta^{18} \mathrm{O}_{s w}$ decrease. Nevertheless, temperature variability of $\sim 2^{\circ} \mathrm{C}$ could mask $\sim 0.44 \%$ o $\delta^{18} \mathrm{O}_{s w}$ variability based on a recent calibration (Lynch-Stieglitz et al., 1999), reflecting some combination of highfrequency salinity and ice volume effects.

In this paper, we present high-resolution late Oligocene Cibicidoides mundulus stable isotope records from deep Pacific Hole 1237B, tied to the new geomagnetic timescale (GTS 2004) (Gradstein et al., 2004). These data define the magnitude and timing of the late Oligocene $\delta^{18} \mathrm{O}$ decrease and associated $\delta^{13} \mathrm{C}$ changes in the deep Pacific Ocean. Comparison of $\delta^{13} \mathrm{C}$ records with those from the other major ocean basins addresses the role of Atlantic-Pacific deep circulation in this climate transition.
F1. Cenozoic $\delta^{18} \mathrm{O}$ data, p. 10.

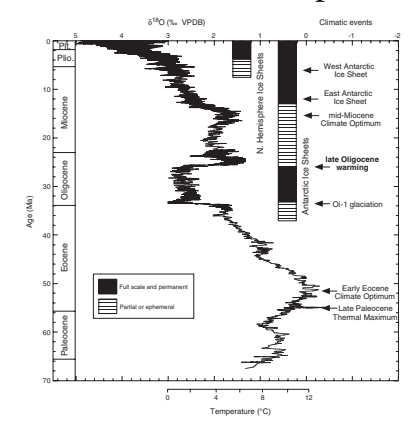




\section{TECTONIC AND OCEANOGRAPHIC SETTING}

Site 1237 (proposed Site NAZCA-17A) was drilled at $16^{\circ} 0.421^{\prime} \mathrm{S}$, $76^{\circ} 22.685^{\prime} \mathrm{W}$ (Shipboard Scientific Party, 2003) on the easternmost flank of Nazca Rise about $140 \mathrm{~km}$ off Peru in $3212 \mathrm{~m}$ water depth (Fig. F2). Site 1237 overlies oceanic crust with an estimated age of 40-45 Ma based on seafloor magnetic anomalies (Cande and Haxby, 1991). Nazca Rise, a fossil hotspot track with its present-day expression at Easter Island, has moved eastward by $\sim 20^{\circ}$ toward the Peru-Chile Trench since $42 \mathrm{Ma}$. Because thermal subsidence effects are difficult to constrain on this oceanic rise, it is not known how shallow Site 1237 was during its early history. Another complication is extensive deformation and faulting prior to subduction of the Nazca plate beneath Peru; however, benthic foraminiferal assemblages indicate a middle to lower bathyal depth in the late Oligocene (A.E. Holbourn et al., pers. comm. 2005).

Site 1237 is located near the eastern edge of the northward-flowing Peru-Chile Current (a.k.a., the Humboldt Current) that forms the cold eastern boundary current of the South Pacific subtropical gyre. Its modern position is within the productive upwelling system off Peru. In its early history, Site 1237 lay in the oligotrophic subtropical gyre, and therefore biologic production and biogenic sedimentation rates were lower. The present-day water depth of Site 1237 lies in a mixing zone of relatively oxygen rich (nutrient depleted) Circumpolar Deep Water that enters the Peru Basin as bottom water through the Peru-Chile Trench and relatively oxygen depleted (nutrient rich) Pacific Central Water (PCW) (Lonsdale, 1976; Tsuchiya and Talley, 1998) (Fig. F3). Tectonic backtracking to shallower depths suggests that Site 1237 lay within the equivalent of modern PCW during the Oligocene (Shipboard Scientific Party, 2003).

\section{MATERIALS AND METHODS}

Hole $1237 \mathrm{~B}$ was cored by double advanced piston coring to a depth of nearly 360 meters composite depth (mcd), reaching sediments of early Oligocene age. Paleomagnetic inclination data (25-mT demagnetization on the shipboard pass-through magnetometer) reveal detailed records of late Oligocene Chrons 7Ar to 9n in Core 202-1237B-31H (Shipboard Scientific Party, 2003). In particular, three reversals are recorded in this core, which span 281.0-290.5 meters below seafloor and 316.41-327.07 mcd (Fig. F4). Interpretation of these paleomagnetic chrons is supported by biostratigraphic data. The late Oligocene calcareous nannofossil zonal boundary NP24/NP25 (27.3 Ma) lies near the base of this core, and the planktonic foraminifer zonal boundary P21/ P22 (26.8 Ma) lies within the core (Shipboard Scientific Party, 2003). These ages are obtained by magnetobiostratigraphic correlations (Berggren et al., 1995) updated to the GTS 2004 (Gradstein et al., 2004).

Samples of $20 \mathrm{~cm}^{3}$ were taken at $5-\mathrm{cm}$ intervals from Core 202$1237 \mathrm{~B}-31 \mathrm{H}$, freeze-dried, weighed, washed over a $63-\mu \mathrm{m}$ sieve, ovendried at $<50^{\circ} \mathrm{C}$, and picked for $C$. mundulus from the $>150$ - $\mu \mathrm{m}$ size fraction. Where possible, four to eight C. mundulus specimens (40-100 $\mu \mathrm{g}$ ) were used for stable isotope analysis. Oxygen and carbon isotope data were generated using a ThermoFinnigan MAT Delta Plus XL stable isotope ratio mass spectrometer (SIRMS) equipped with a Kiel III automated carbonate preparation device. External precision, based on
F2. Location map, p. 11.

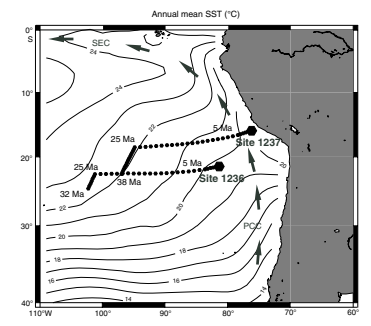

F3. Meridional cross-section, p. 12.

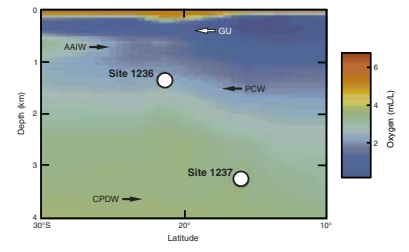

F4. Magnetic polarity and $\delta^{18} \mathrm{O}$ data vs. depth, p. 13.

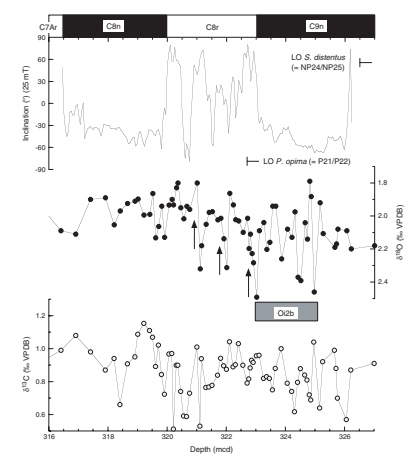


$>1000$ National Institute of Standards and Technology (NBS)-19 standards run since July 2000, is better than $\pm 0.08 \%$ o for $\delta^{18} \mathrm{O}$ and $\pm 0.04 \%$ o for $\delta^{13} \mathrm{C}$. Estimated precision based on replicate analyses is $\pm 0.15 \%$ o for $\delta^{18} \mathrm{O}$ and $\pm 0.07 \%$ for $\delta^{13} \mathrm{C}(n=6)$. Data are reported relative to the Vienna Peedee belemnite carbonate standard. Coarse fraction data are calculated as weight of the $>63-\mu \mathrm{m}$ size fraction divided by dry bulk weight and expressed as percentage. Planktonic foraminifers were also studied in selected samples to refine the biostratigraphy. Supporting data are available electronically in the Janus database (wwwodp.tamu.edu/database/) and in the CHRONOS Data Repository (www.chronos.org).

\section{RESULTS}

Oxygen isotope $\delta^{18} \mathrm{O}$ values in C. mundulus exhibit a series of $0.1 \% 0-$ $0.6 \%$ variations from 316.41 to $327.07 \mathrm{mcd}$ in Core $202-1237 \mathrm{~B}-31 \mathrm{H}$ (Fig. F4). Highest values reaching $\sim 2.4 \%$ are recorded in upper Chron 9 n. Lowest values reaching $\sim 1.8 \%$ are recorded in upper Chron 8 r. Superimposed upon the mean decrease of $\sim 0.30$ is a series of three steps from 323 to 321 mcd within Chron 8r (27.027-26.554 Ma in GTS 2004). The initial decrease at 322.9 mcd is closely associated with the last occurrence of Paragloborotalia opima (P21/P22 planktonic foraminifer zonal boundary) between Samples 202-1237B-31H-5, $10 \mathrm{~cm}$, and $31 \mathrm{H}-5,61 \mathrm{~cm}(322.51-322.76 \mathrm{mcd})$, in lowermost Chron 8r.

Carbon isotope $\delta^{13} \mathrm{C}$ values exhibit a series of $0.1 \% 0-0.6 \%$ variations, including a distinct positive excursion of $\sim 0.5 \%$ o between 321.6 and 318.4 mcd (Fig. F4). Lowest values reaching $\sim 0.5 \%$ are recorded in upper Chron 8r, and highest values reaching $\sim 1.1 \%$ are recorded in lower Chron $8 \mathrm{n}$. The $\delta^{13} \mathrm{C}$ maximum at $319.2 \mathrm{mcd}$ occurs $2 \mathrm{~m}$ above the final decrease in C. mundulus $\delta^{18} \mathrm{O}$ at $321 \mathrm{mcd}$.

\section{DISCUSSION}

\section{Stratigraphic Correlations}

Linear interpolation between inclination reversals recorded in Core 202-1237B-31H (Fig. F4) and the base of Chron 9n in Core 32H (Shipboard Scientific Party, 2003) is used to develop the age model. Calibration to the new GTS 2004 (Gradstein et al., 2004) indicates an age span from $\sim 27.2$ to $25.3 \mathrm{Ma}$ and sedimentation rates ranging from 4.05 to $6.79 \mathrm{~m} / \mathrm{m} . \mathrm{y}$.

Magnetic polarity stratigraphy and oxygen isotope data from Core 202-1237B-31H confirm some previously suggested correlations. In particular, high C. mundulus $\delta^{18} \mathrm{O}$ values in upper Chron $9 \mathrm{n}$ are considered to define Oi2b, the last in a series of distinct $\delta^{18} \mathrm{O}$ maxima in the Oligocene (Miller et al., 1991). This association has been found at Deep Sea Drilling Project (DSDP) Site 529 (Miller et al., 1991), whereas Oi2b is recorded in Chron 8r at Site 522 (Miller et al., 1988). This $\delta^{18} \mathrm{O}$ maximum may also correlate with glacial marine sequences in the Ross Sea (Leckie and Webb, 1986). Here we confirm that the highest values interpreted to represent Oi2b are recorded in upper Chron 9n (0.30-0.60) after the late Oligocene $\delta^{18} \mathrm{O}$ decrease. The initial C. mundulus $\delta^{18} \mathrm{O}$ decrease at 26.7 Ma is associated with the last occurrence of P. opima (P21/P22 planktonic foraminifer zonal boundary) between 322.51 and 322.76 
mcd in lowermost Chron 8r. This zonal boundary may represent a useful marker for the initiation of the Chron $8 \mathrm{r} \delta^{18} \mathrm{O}$ shift.

The transition from Oi2b to the late Oligocene climate optimum appears to span nearly all of Chron 8r (27.027-26.554 Ma in GTS 2004) (Fig. F5). This transition is composed of three temporary decreases of $0.3 \% 0-0.5 \%$ at $\sim 26.7,26.5$, and $26.35 \mathrm{Ma}$ based on an assumed constant sedimentation rate of $5.52 \mathrm{~m} / \mathrm{m}$.y. in Chron 8r. The final decrease to low C. mundulus $\delta^{18} \mathrm{O}$ values occurs in upper Chron $8 \mathrm{r}$ and marks the initiation of the late Oligocene climatic optimum and is here termed the "Chron $8 \mathrm{r} \delta^{18} \mathrm{O}$ shift." The amplitude of our $\delta^{18} \mathrm{O}$ variations is somewhat less than predicted by recent reconstructions of sea level variability in the Oligocene (Pekar and Miller, 1996; Kominz and Pekar, 2001; Pekar et al., 2002), but we have not estimated the influence of deepwater temperature variability on our $\delta^{18} \mathrm{O}$ record.

Despite the lack of independent deepwater temperature proxy data, our $\delta^{18} \mathrm{O}$ record can be used to test the idea that a significant reversal of the long-term "greenhouse to icehouse" trend was initiated by rapid deep-sea warming during the late Oligocene (Zachos et al., 2001). Understanding this reversal in the Cenozoic greenhouse to icehouse trend has important implications for the stability of polar ice sheets. In particular, if ice mass equivalent to the modern-day Antarctic ice disappeared at this time, it might strengthen the case for an unstable East Antarctic Ice Sheet; however, our data and those of Lear et al. (2004) indicate that the late Oligocene $\delta^{18} \mathrm{O}$ decrease was much less than that reconstructed based on spliced records from different ocean basins (Zachos et al., 2001). Modest changes in Antarctic ice volume are more in line with evidence for persistent grounded ice in the Ross Sea during the late Oligocene (Hayes and Frakes, 1975; Leckie and Webb, 1986; DeSantis et al., 1995) and terrestrial evidence that indicates temperate climates throughout the late Oligocene (Askin, 1992).

Our stable isotope data resolution $(\sim 10-20 \mathrm{~cm}$ sampling) is not sufficient to define the full spectrum of orbital-scale variability. The $\delta^{18} \mathrm{O}$ values hint at substantial glacial-interglacial cycles of $\sim 0.6 \%$ amplitude, particularly from $\sim 26.7$ to $26.3 \mathrm{Ma}$ during the Chron $8 \mathrm{r} \delta^{18} \mathrm{O}$ shift (Fig. F5). Visual inspection shows three distinct episodes in $<400 \mathrm{k} . \mathrm{y}$. that may reflect climate cycles in the eccentricity band. In addition, percent coarse fraction data $(5 \mathrm{~cm}$ sampling) exhibit considerable variability in the 100 - to $400-\mathrm{k} . \mathrm{y}$. band during the $\sim 27.2$ to $26.3 \mathrm{Ma}$ interval, indicating a promising interval for further study. Percent coarse fraction is controlled by a combination of carbonate production and preservation, including corrosivity to carbonate due to deep ocean ventilation and circulation changes. Our $\delta^{13} \mathrm{C}$ data, another index of deep ocean ventilation and circulation changes, do not exhibit a clear relation to $\delta^{18} \mathrm{O}$ at the current resolution.

\section{Indo-Pacific and Atlantic Deep Circulation}

Our late Oligocene C. mundulus $\delta^{13} \mathrm{C}$ data can be compared with similar existing records from the North Atlantic, Southern, and Indian Oceans to investigate large-scale circulation patterns. The long-term variations in deepwater dissolved inorganic carbon $\delta^{13} \mathrm{C}$ recorded by benthic foraminifers are controlled by reservoir changes in carbon cycling, mainly the relative proportion of carbon deposited as organic and inorganic carbon; however, interocean $\delta^{13} \mathrm{C}$ gradients at a given time reflect aging of deep waters as they accumulate remineralization products
F5. $\delta^{18} \mathrm{O}$ and coarse fraction data vs. age, p. 14.

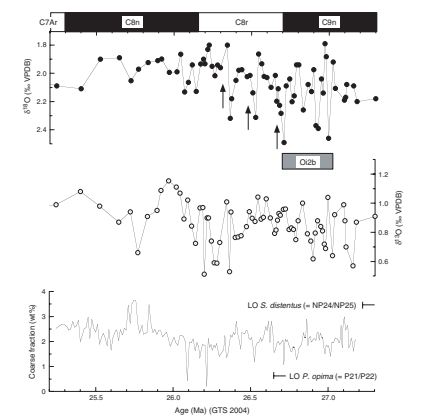


along the flow path (Broecker and Peng, 1982). This approach has been used by many other workers investigating Paleogene deep circulation (e.g., Miller and Fairbanks, 1985; Wright and Miller, 1993). Accordingly, Cibicidoides $\delta^{13} \mathrm{C}$ records from these regions were placed on a common timescale by an integrated paleomagnetic and oxygen isotope stratigraphy (Zachos et al., 1996, 2001) and updated to the GTS 2004 (Gradstein et al., 2004).

Examination of Cibicidoides $\delta^{13} \mathrm{C}$ records from North Atlantic DSDP Site $563\left(33^{\circ} 38.53^{\prime} \mathrm{N}, 43^{\circ} 46.04^{\prime} \mathrm{W}\right.$; water depth $\left.=3786 \mathrm{~m}\right)$, Southern Ocean ODP Site $689\left(64^{\circ} 31.01^{\prime} \mathrm{S}, 03^{\circ} 05.99^{\prime} \mathrm{E}\right.$; water depth $\left.=2200 \mathrm{~m}\right)$, Indian Ocean ODP Site $744\left(61^{\circ} 34.66^{\prime} \mathrm{S}, 80^{\circ} 35.46^{\prime} \mathrm{E}\right.$; water depth $=2307$ $\mathrm{m})$, and Southeast Pacific Ocean Site 1237 reveals interocean gradients very different from the modern ocean (Fig. F6). These records have been correlated to Site 1237 based on magnetic polarity stratigraphy updated to GTS 2004. Interocean $\delta^{13} \mathrm{C}$ gradients are small during the late Oligocene $(<0.5 \%)$ Throughout most of the interval studied, however, the highest $\delta^{13} \mathrm{C}$ values (youngest deep waters) are recorded at Indian Ocean Site 744 and Pacific Ocean Site 1237, while the lowest values (oldest deep waters) are recorded at North Atlantic Site 563 with intermediate values at Southern Ocean Site 689. Such a pattern is consistent with an Indo-Pacific to Atlantic aging of deep water during the late Oligocene, as suggested by earlier work (Kennett and Stott, 1990). No major change in this pattern is observed in association with the late Oligocene climate transition, but the uncertainties of interocean correlation based on paleomagnetic data with different stratigraphic resolution require caution in interpreting this finding.

\section{CONCLUSIONS}

Oxygen isotope $\delta^{18} \mathrm{O}$ values in the benthic foraminifer C. mundulus decrease from values of $\sim 2.20 \%$ in upper Chron $9 \mathrm{n}$ (Oi2b of Miller et al., 1991) to values of $\sim 1.90 \%$ in upper Chron 8 r. The decrease $(0.30$ 0.60 ) occurs within Chron $8 \mathrm{r}$ in three steps at $\sim 26.7,26.5$, and $26.35 \mathrm{Ma}$ (GTS 2004) and is here termed the "Chron $8 \mathrm{r} \delta^{18} \mathrm{O}$ shift." The final decrease at $\sim 26.35$ Ma marks the initiation of the late Oligocene climatic optimum. The initial decrease at $26.7 \mathrm{Ma}$ is closely associated with the last occurrence of $P$. opima (P21/P22 planktonic foraminifer zonal boundary) between 322.51 and 322.76 mcd in lowermost Chron 8r. This zonal boundary may represent a useful marker for the Chron $8 \mathrm{r}$ $\delta^{18} \mathrm{O}$ shift. Overall, this study is a modest step toward an integrated magnetic polarity and astronomical chronostratigraphy for the late Oligocene based on Site 1237.

\section{ACKNOWLEDGMENTS}

This work was supported by the Joint Oceanographic InstitutionsScience Support Program (JOI-USSSP) (grant 418920-BA344 to B. Flower). This research used samples and/or data provided by the Ocean Drilling Program (ODP) (under sample request 18034B). ODP is sponsored by the U.S. National Science Foundation (NSF) and participating countries under the management of Joint Oceanographic Institutions (JOI), Inc. Kate Chisholm was supported by a University of South Florida College of Marine Science/Eckerd College summer internship for 2004. We thank Ann Holbourn and Mark Leckie for thoughtful reviews,
F6. $\delta^{13} \mathrm{C}$ data vs. age, p. 15 .

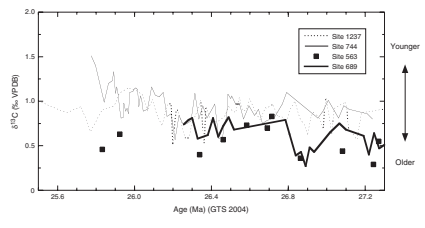


B.P. Flower AND K.E. Chisholm

MAgNETOSTRATIGRAPHiC CALIBRATION

Ilsa Johansen for laboratory assistance, and Ethan Goddard for maintenance of the SIRMS in the College of Marine Science. 


\section{REFERENCES}

Askin, R.A., 1992. Late Cretaceous-early Tertiary outcrop evidence for past vegetation and climates. In Kennett, J.P., and Warnke, D.A., (Eds.), The Antarctic Paleoenvironment: A Perspective on Global Change, Part I. Antarct. Res. Ser., 56:61-74.

Barrera, E., and Huber, B.T., 1991. Paleogene and early Neogene oceanography of the southern Indian Ocean: Leg 119 foraminifer stable isotope results. In Barron, J., Larsen, B., et al., Proc. ODP, Sci. Results, 119: College Station, TX (Ocean Drilling Program), 693-717.

Berggren, F.C., Kent, D.V., Swisher, C.C., III, and Aubry, M.-P., 1995. A revised Cenozoic geochronology and chronostratigraphy. In Berggren, W.A., Kent, D.V., Aubry, M.-P., and Hardenbol, J. (Eds.), Geochronology, Time Scales and Global Stratigraphic Correlation. Spec Publ._SEPM (Soc. Sediment. Geol.), 54:129-212.

Billups, K., and Schrag, D.P., 2002. Paleotemperature and ice volume of the past 27 Myr revisited with paired $\mathrm{Mg} / \mathrm{Ca}$ and ${ }^{18} \mathrm{O} /{ }^{16} \mathrm{O}$ measurements on benthic foraminifera. Paleoceanography, 17. doi:10.1029/2000PA000567

Broecker, W.S., and Peng, T.-H., 1982. Tracers in the Sea: Palisades, NY (Eldigio Press).

Cande, S.C., and Haxby, W.F., 1991. Eocene propagating rifts in the southwest Pacific and their conjugate features on the Nazca plate. J. Geophys. Res., 96:19609-19622.

DeSantis, L., Anderson, J.B., Brancolini, G., and Zayatz, I., 1995. Seismic record of late Oligocene through early Miocene glaciation on the central and eastern continental shelf of the Ross Sea. In Cooper, A.K., Barker, P.F., and Brancolini, G., (Eds.), Geology and Seismic Stratigraphy of the Antarctic Margin. Antarct. Res. Ser., 68:235245.

Flower, B.P., 1999. Cenozoic deep-sea temperatures and polar glaciation: the oxygen isotope record. In Barrett, P., and Orombelli, G. (Eds.), Proceedings of the Workshop: Geological Records of Global and Planetary Changes. Terra Antart. Rep., 3:27-42.

Gradstein, F.M., Ogg, J.G., and Smith, A. (Eds.), 2004. A Geologic Time Scale 2004: Cambridge (Cambridge Univ. Press).

Hayes, D.E., and Frakes, L.A., 1975. General synthesis, Deep Sea Drilling Project, Leg 28. In Hayes, D.E., Frakes, L.A., et al., Init. Repts. DSDP, 28: Washington (Govt. Printing Office), 919-924.

Kennett, J.P., and Stott, L.D., 1990. Proteus and Proto-oceanus: ancestral Paleogene oceans as revealed from Antarctic stable isotopic results: ODP Leg 113. In Barker, P.F., Kennett, J.P., et al., Proc. ODP, Sci. Results, 113: College Station, TX (Ocean Drilling Program), 865-880.

Kominz, M.A., and Pekar, S.F., 2001. Oligocene eustasy from two-dimensional sequence stratigraphic backstripping. Geol. Soc. Am. Bull., 113:291-304.

Lear, C.H., Elderfield, H., and Wilson, P.A., 2000. Cenozoic deep-sea temperatures and global ice volumes from $\mathrm{Mg} / \mathrm{Ca}$ in benthic foraminiferal calcite. Science, 287:269272.

Lear, C.H., Rosenthal, Y., Coxall, H.K., and Wilson, P.A., 2004. Late Eocene to early Miocene ice-sheet dynamics and the global carbon cycle. Paleoceanography, 19:PA4015. doi:10.1029/2004PA001039

Leckie, R.M., and Webb, P.-N., 1986. Late Paleogene and early Neogene foraminifers of Deep Sea Drilling Project Site 270, Ross Sea, Antarctica. In Kennett, J.P., von der Borch, C.C., et al., Init. Repts. DSDP, 90: Washington (U.S. Govt. Printing Office), 1093-1142.

Levitus, S., Conkright, M.E., Reid, J.L., Najjar, R.G., and Mantyla, N.A., 1993. Distribution of nitrate, phosphate, and silicate in the world oceans. Prog. Oceanogr., 31:245-273.

Lonsdale, P., 1976. Abyssal circulation of the southeastern Pacific and some geological implications. J. Geophys. Res., 81:1163-1176. 
Lynch-Stieglitz, J., Curry, W.B., and Slowey, N., 1999. A geostrophic transport estimate for the Florida Current from the oxygen isotope composition of benthic foraminifera. Paleoceanography, 14:360-373.

Martin, P.A., Lea, D.W., Rosenthal, Y., Shackleton, N.J., Sarnthein, M., and Papenfuss, T., 2002. Quaternary deep-sea temperature histories derived from benthic foraminifer Mg/Ca. Earth Planet. Sci. Lett., 198:193-209.

Miller, K.G., and Fairbanks, R.G., 1985. Oligocene to Miocene carbon isotope cycles and abyssal circulation changes. In Sundquist, E.J., and Broecker, W.S. (Eds.), The Carbon Cycle and Atmospheric $\mathrm{CO}_{2}$ : Natural Variations Archean to Present. Geophys. Monogr., 32:469-486.

Miller, K.G., Fairbanks, R.G., and Mountain, G.S., 1987. Tertiary oxygen isotope synthesis, sea-level history, and continental margin erosion. Paleoceanography, 2:1-19.

Miller, K.G., Feigenson, M.D., Kent, D.V., and Olsson, R.K., 1988. Upper Eocene to Oligocene isotope $\left({ }^{87} \mathrm{Sr} /{ }^{86} \mathrm{Sr}, \delta^{18} \mathrm{O}, \delta^{13} \mathrm{C}\right)$ standard section, Deep Sea Drilling Project Site 522. Paleoceanography, 3:223-233.

Miller, K.G., Wright, J.D., and Fairbanks, R.G., 1991. Unlocking the Ice House: Oligocene-Miocene oxygen isotopes, eustasy, and margin erosion. J. Geophys. Res., 96:6829-6848.

Pekar, S.F., Christie-Blick, N., Kominz, M.A., and Miller, K.G., 2002. Calibration between eustatic estimates from backstripping and oxygen isotopic records for the Oligocene. Geology, 30:903-906.

Pekar, S.F., and Miller, K.G., 1996. New Jersey Oligocene "Icehouse" sequences (ODP Leg 150X) correlated with global $\delta^{18} \mathrm{O}$ and Exxon eustatic records. Geology, 24:567570 .

Shipboard Scientific Party, 2003. Site 1237. In Mix, A.C., Tiedemann, R., Blum, P., et al., Proc. ODP, Init. Repts., 202, 1-107 [CD-ROM]. Available from: Ocean Drilling Program, Texas A\&M University, College Station TX 77845-9547, USA. [HTML]

Tsuchiya, M., and Talley, L.D., 1998. A Pacific hydrographic section at $88^{\circ} \mathrm{W}$ : waterproperty distribution. J. Geophys. Res., 103:12899-12918.

Wright, J.D., and Miller, K.G., 1993. Southern Ocean influences on late Eocene to Miocene deep-water circulation. In Kennett, J.P., and Warnke, D.A. (Eds.), The Antarctic Paleoenvironment: A Perspective on Global Change. Antarct. Res. Ser., 60:1-25.

Zachos, J.C., Pagani, M., Sloan, L., Thomas, E. and Billups, K., 2001. Trends, rhythms, and aberrations in global climate $65 \mathrm{Ma}$ to present. Science, 292:686-693.

Zachos, J.C., Quinn, R.M., and Salamy, K., 1996. High resolution $\left(10^{4} \mathrm{yr}\right)$ deep-sea foraminiferal stable isotope records of the Eocene-Oligocene climate transition. Paleoceanography, 11:251-266. 


\section{B.P. Flower ANd K.E. Chisholm

Figure F1. Compilation of benthic oxygen isotope data from Cenozoic deep-sea cores (after Zachos et al., 2001). Note prominent $\delta^{18} \mathrm{O}$ decrease of $>1 \%$ during the late Oligocene at $\sim 26 \mathrm{Ma}$ against the long-term Cenozoic $\delta^{18} \mathrm{O}$ increase. VPDB = Vienna Peedee belemnite.

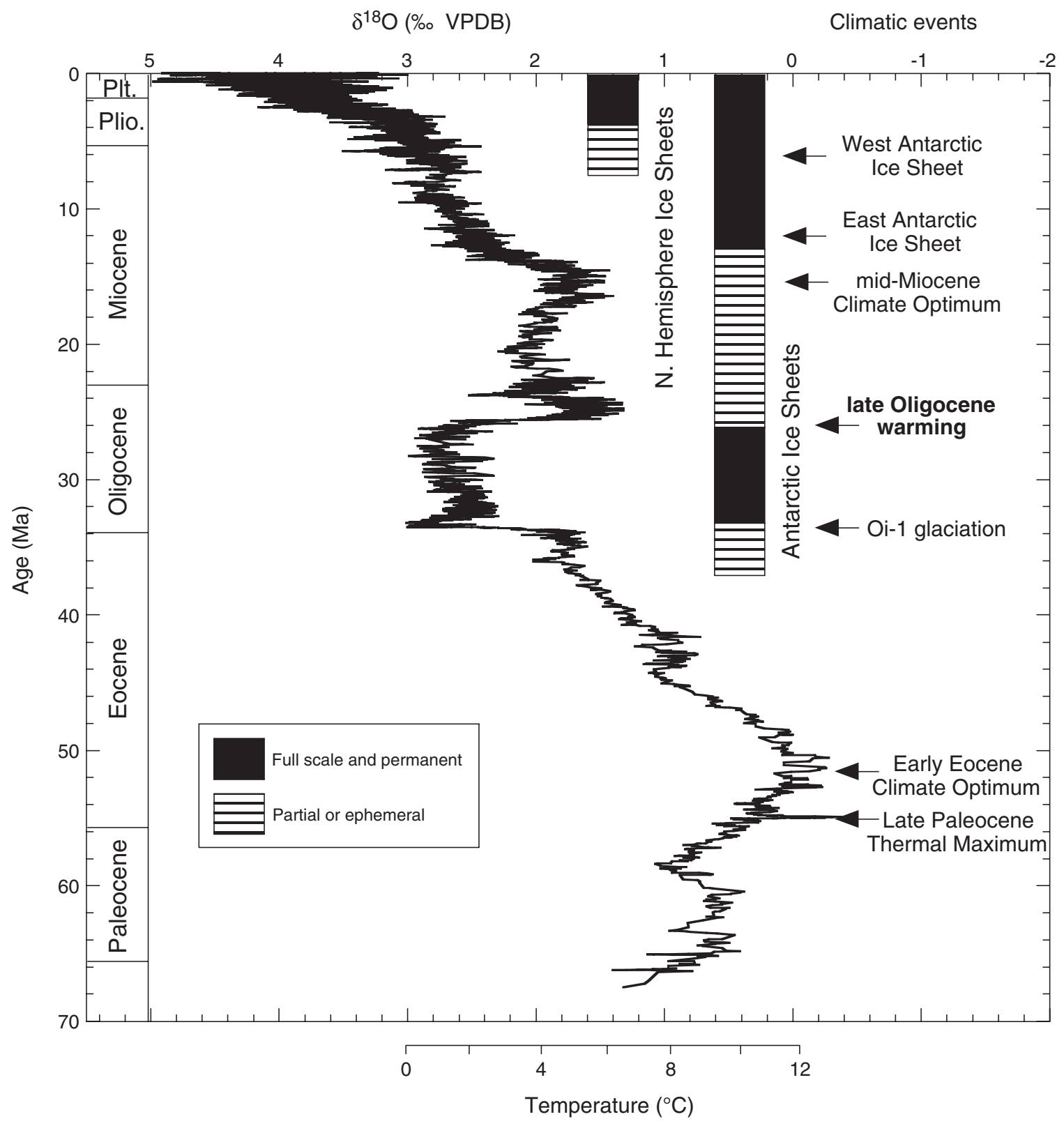


Figure F2. Location map (Shipboard Scientific Party, 2003) showing Sites 1237 and 1236 on Nazca Ridge and their tectonic backtrack paths, plus annual mean sea-surface temperature (SST). Note that Site 1237 was within the subtropical South Pacific gyre during the late Oligocene. Also shown are positions of the PeruChile Current (PCC) and the South Equatorial Current (SEC).

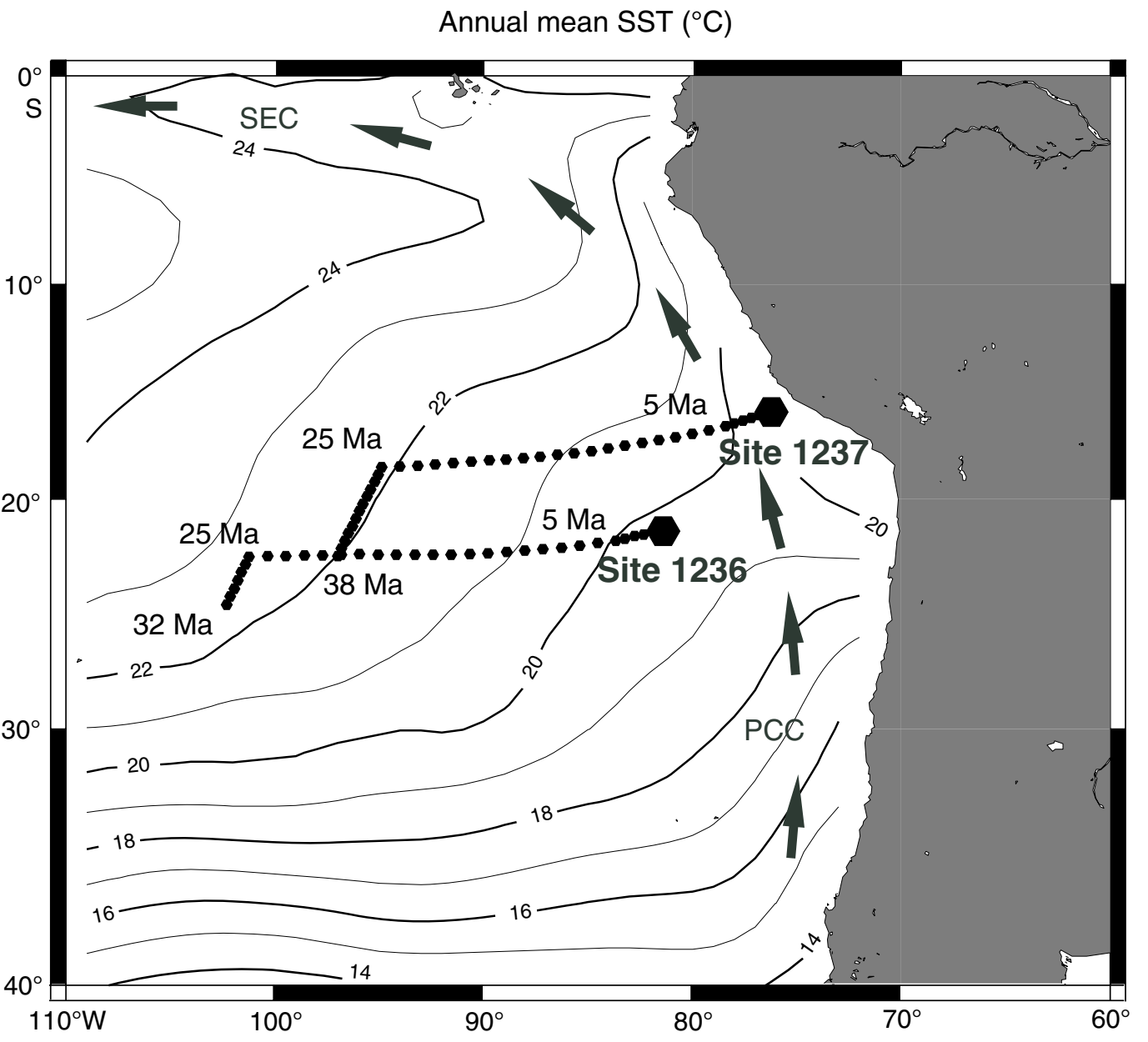




\section{B.P. Flower ANd K.E. Chisholm

Figure F3. Meridional cross-section of southeastern Pacific (Shipboard Scientific Party, 2003) showing water masses based on dissolved oxygen concentrations (Levitus et al., 1993). Site 1237 at 3212 meters water depth is shown in relation to Pacific Central Water (PCW), Circumpolar Deep Water (CPDW), Antarctic Intermediate Water (AAIW), and Gunther Undercurrent (GU). During the late Oligocene, Site 1237 was probably at a shallower water depth and in the mixing zone between PCW and CPDW.

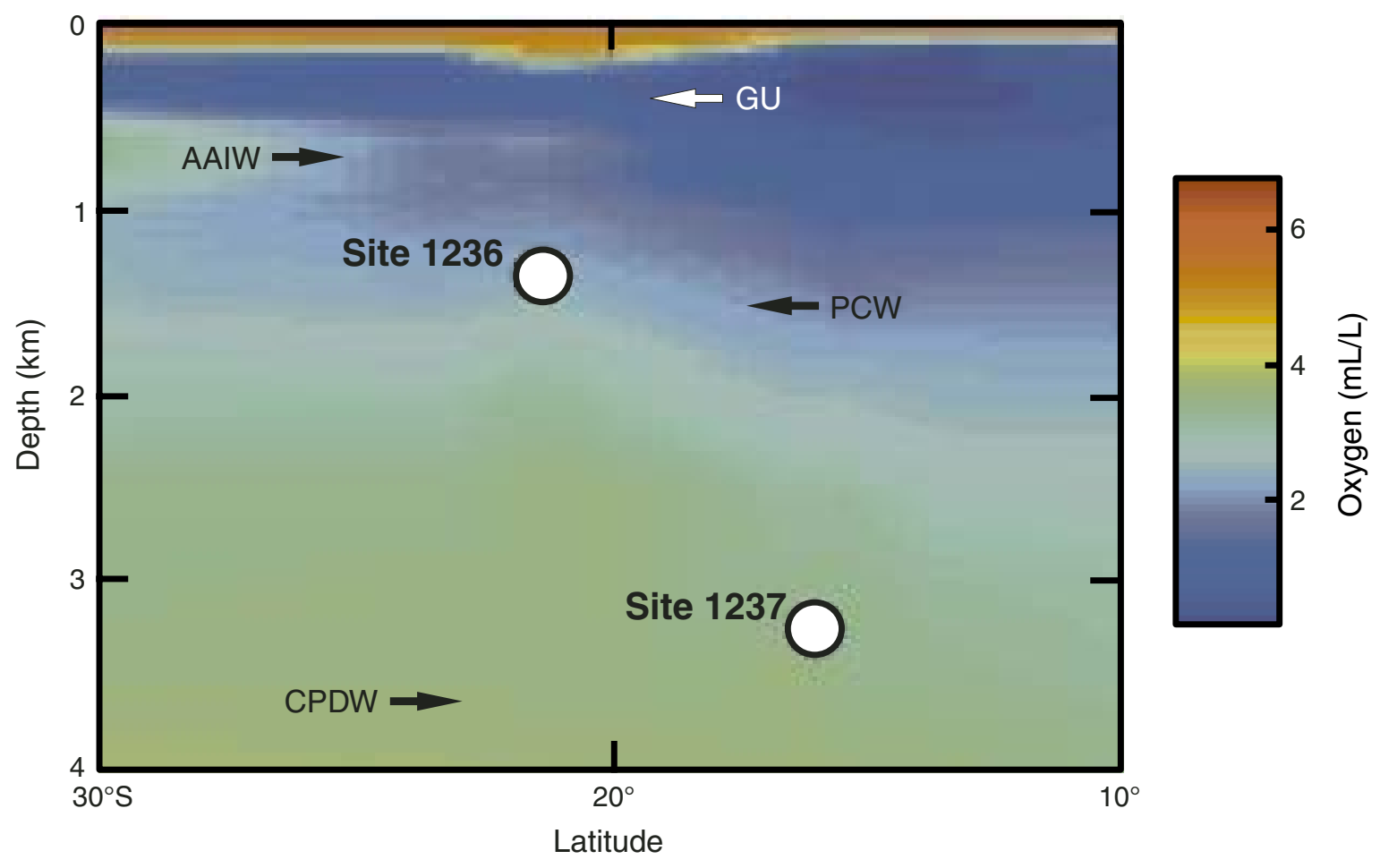




\section{B.P. Flower ANd K.E. Chisholm

Figure F4. Magnetic polarity data (inclination after 25-mT demagnetization on the shipboard pass-through magnetometer) and stable isotope data (based on the benthic foraminifer Cibicidoides mundulus) vs. depth in Core 202-1237B-31H. Also shown are interpreted paleomagnetic Chrons 7Ar to 9n and last occurrence (LO) of the calcareous nannofossil Sphenolithus distentus (Shipboard Scientific Party, 2003) and LO of the planktonic foraminifer Paragloborotalia opima (this study). The late Oligocene climate transition occurs as a three-step decrease in $\delta^{18} \mathrm{O}$ within Chron $8 \mathrm{r}$ (here termed the "Chron $8 \mathrm{r} \delta^{18} \mathrm{O}$ shift"), immediately following Oi2b of Miller et al. (1991). VPDB = Vienna Peedee belemnite.

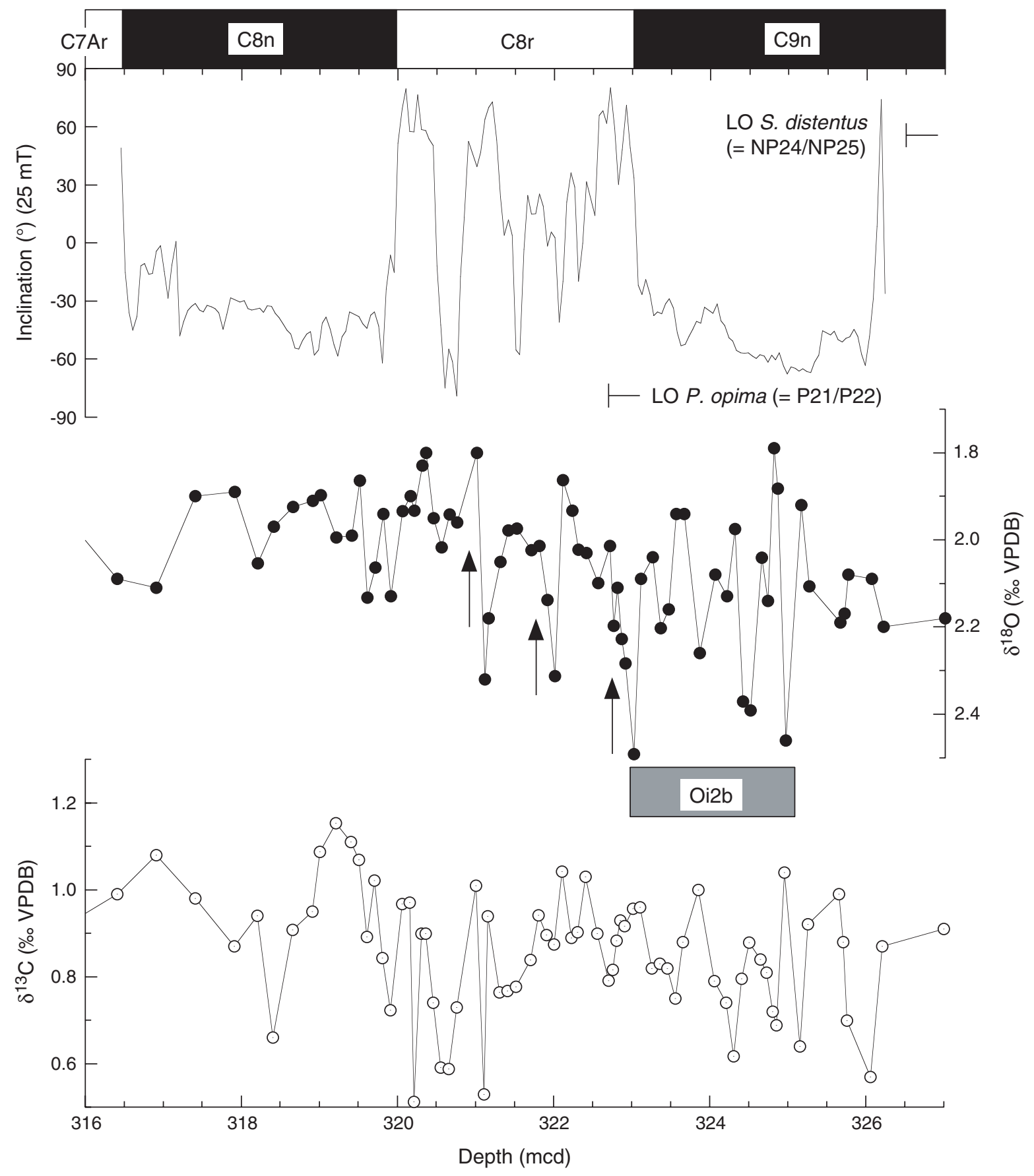


Figure F5. Stable isotope (based on Cibicidoides mundulus) and percent coarse fraction (weight percentage of the $>63-\mu \mathrm{m}$ fraction) data vs. age in million years before present (Ma) in Core 202-1237B-31H. Also shown are paleomagnetic Chrons 7Ar to 9n (Gradstein et al., 2004) and last occurrence (LO) of the calcareous nannofossil Sphenolithus distentus (Shipboard Scientific Party, 2003) and LO of the planktonic foraminifer Paragloborotalia opima (this study). The initiation of the Chron $8 \mathrm{r} \delta^{18} \mathrm{O}$ shift is associated with LO of $P$. opima. VPDB = Vienna Peedee belemnite.
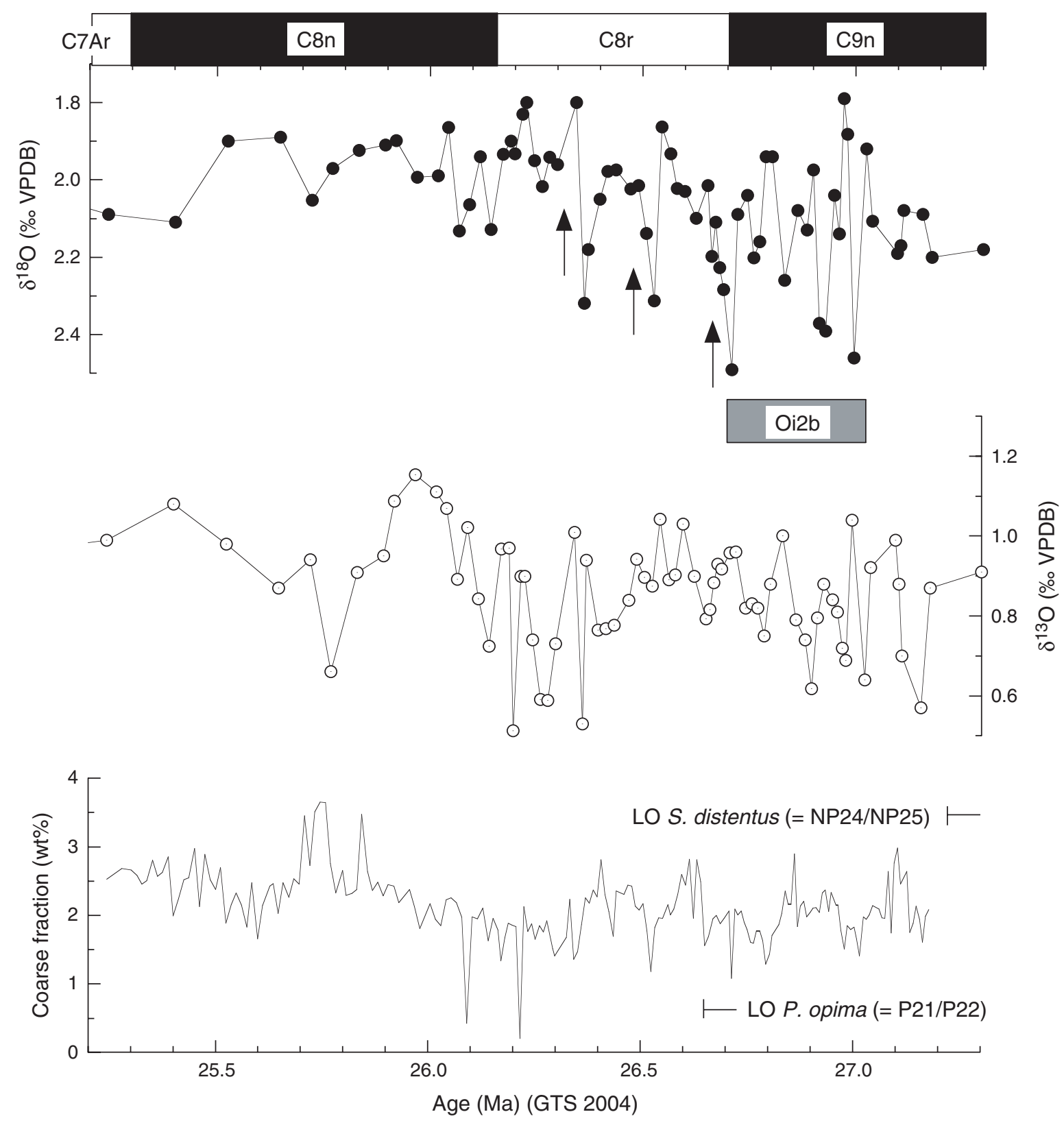


\section{B.P. FloWER AND K.E. CHISHOLM \\ MAgnetostratigraphic CALibration}

Figure F6. Stable carbon isotope data (based on Cibicidoides mundulus) from southeast Pacific Site 1237 (this study), southern Indian Ocean Site 744 (Barrera and Huber, 1992), North Atlantic Site 563 (Miller and Fairbanks, 1985), and Southern Ocean Site 689 (Kennett and Stott, 1990). Higher and lower $\delta^{13} \mathrm{C}$ values indicate younger and older deep waters, respectively. Interocean $\delta^{13} \mathrm{C}$ gradients are small during the late Oligocene $(<0.5 \%)$, but consistent with an Indo-Pacific to Atlantic aging of deep waters. VPDB $=$ Vienna Peedee belemnite.

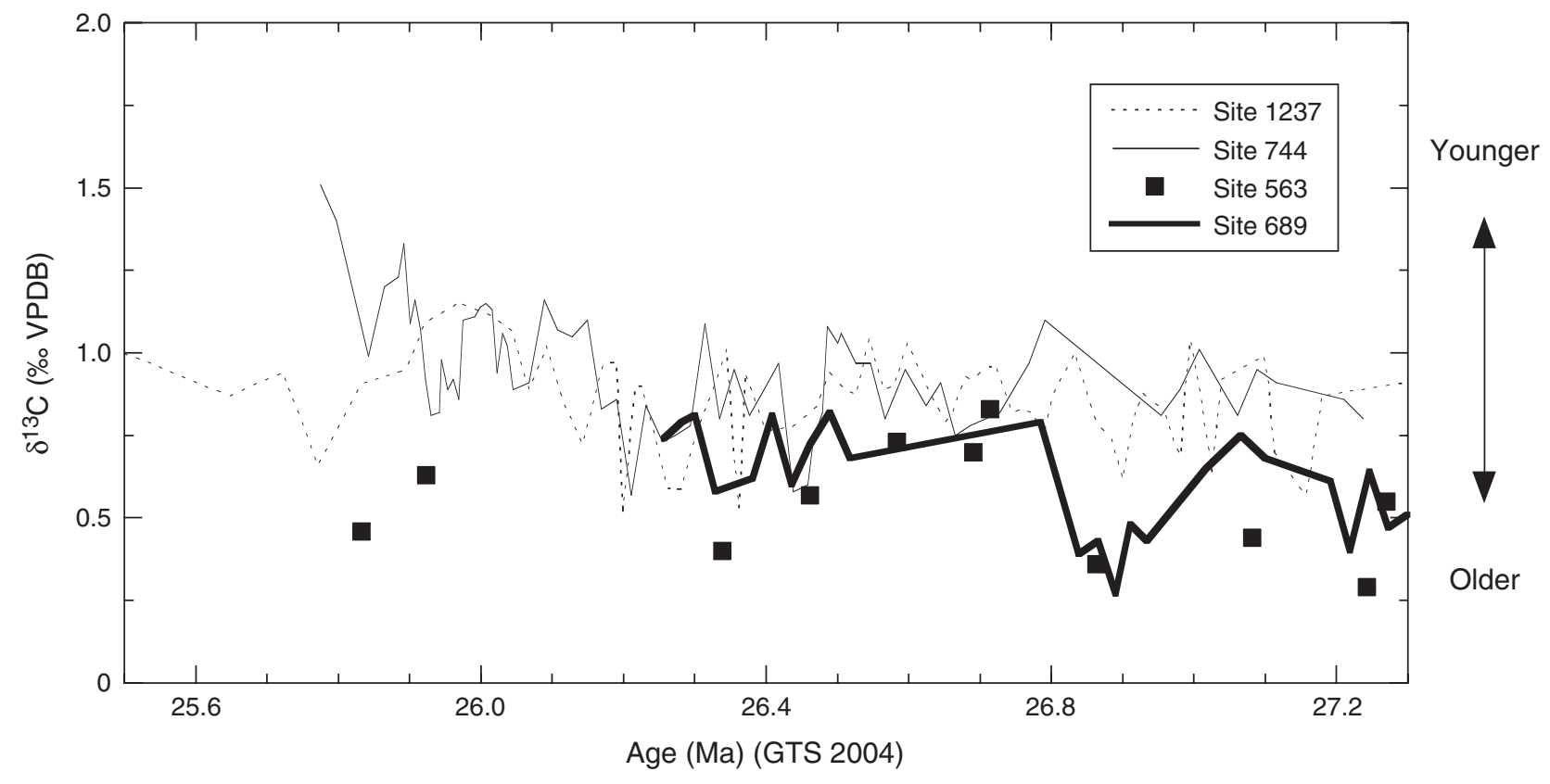

